\title{
Travel lifestyle preferences and destination activity choices of Slow Food members and non- members
}

Lee, Kuan -Hee, Packer, J., \& Scott, N. (2015) Travel lifestyle preferences and destination activity choices of Slow Food members and non-members. Tourism Management, 46 1-10. (20.12.2013)

\begin{abstract}
This paper explores the relationships between travel lifestyle preferences and destination activity choices of Slow Food members and non-members. Food is an important component of Slow Food members' lifestyle, and members practice the Slow Food philosophy in their daily lives. It was therefore expected that lifestyle preferences would influence destination activity choices in different ways for Slow Food members and non-members. This proposition was tested by comparing 337 Slow Food members' and 207 non-members' questionnaire responses. The results suggest that Slow Food members differed significantly from non-members in travel-related lifestyle preferences and destination activity choices. Slow Food members had lower interest in comfortable travel and higher interest in local culture compared with non-members. This study also found travel lifestyle preferences significantly influenced destination activity choices. Independently of the motivation to travel to a destination, this study offered evidence that travel lifestyle preferences influence participants' destination activity choices. An investigation of the impact of the diverse cultural backgrounds of Slow Food members is suggested as a future area of study.
\end{abstract}

Keywords: food tourism, motivation to travel, travel lifestyle, destination activity, Slow Food

\section{Introduction}

Food is an important component in any travel destination and could occupy as much as one third of the total expenditure of a tourist in a destination (Mak, Lumbers, \& Eves, 2012). Food has psychosensorial, social and symbolic meanings and is often associated with destination image and attraction (Ab Karim \& Chi, 2010; Bessiere, 1998; Frochot, 2003). Food can also form part of a peak experience for tourists and influence their decision to revisit a destination (Kim, Kim, Goh, \& Antun, 2011; Quan \& Wang, 2004). Definitions of food tourism, gastronomy tourism, culinary tourism, and gourmet tourism consider food as the primary motivational factor for these groups of tourists to travel (Boniface, 2003; Hall \& Sharples, 2008; Kivela \& Crotts, 2005). For example, the definition of food tourism is "visitation to primary and secondary food producers, food festivals, restaurants and specific locations for which food tasting and/or experiencing the attributes of specialist food production regions are the primary motivating factor for travel” (Hall \& Mitchell, 2001, p. 308). The importance of food in tourism is evidenced by the growing investment of local governments in promoting foodrelated activities in order to attract tourists with food interests (du Rand, Heath, \& Alberts, 2003; Kivela \& Crotts, 2006). Many countries such as Singapore, France or Italy, and cities such as Hong Kong or Adelaide, seek to develop their own culinary image (Au \& Law, 2002).

Although most studies in food tourism have concluded that food is an important motivating factor for tourists to visit a destination, McKercher, Okumus, and Okumus (2008) suggest that some past studies on food tourism are not methodologically sound and do not provide sufficient evidence to support this conclusion. For example, some food tourism studies have inferred motivation to travel from an investigation of activities in the destination. Such studies overestimate the importance of food as a motivation for travel and do not provide evidence of a cause-effect relationship between motivations to travel and the activities undertaken in the destination. The reasons for travelling to a particular destination play an important role in the traveller's decision-making when selecting a vacation 
destination. However, tourist decision-making is an ongoing process that involves different stages (Smallman \& Moore, 2010). The motivation to travel to a destination and the activities undertaken in the destination can be seen as two different processes which may or may not be related. In many cases, tourists' motivations change from one stage of travel to another (Kao, Patterson, Scott, \& Li, 2008; McKercher \& Chan, 2005). Thus, there is a need for food tourism research to move beyond studies of motivation to travel, and to better understand the factors that influence tourists' choices regarding food-related activities in the destination.

To understand food tourists' destination activity choices, it is necessary to first consider how people make decisions. A decision is an outcome of a mental process whereby one action is specifically chosen from a set of available alternatives (Moutinho, 1987). Among all of the different variables that influence decision making, one underlying factor that requires further exploration is lifestyle (Sirakaya \& Woodside, 2005). Veal (1991, p. 19) defines the term lifestyle in the context of leisure: "lifestyle is the pattern of individual and social behaviour characteristic of an individual or a group". A simpler definition of lifestyle for most sociologists is, "a distinctive, hence recognisable, mode of living” (Sobel, 1981, p. 28). Bourdieu (1984, 1990) elaborated the notion of habitus as being related to lifestyle and taste. From Bourdieu's point of view, consumers operate according to practical logic, with economics and cultural capital playing a fundamental role in their decision-making, and embody practical logic according to their own taste. Individuals carry and accumulate past memories and display their lifestyle through the choices they make; hence model of car, brand of clothing, mode of travel, and type of food are all examples of ways that lifestyle can be manifested.

Preferences in travel behaviour form part of personal lifestyle, and may influence both how and why people travel (Chen, Huang, \& Cheng, 2009; Hsu, Tsai, \& Wu, 2009; Lanzendorf, 2002). Lifestyle factors are thus likely to influence tourists' participation in food-related activities at a destination. For example, Wahlers and Etzel (1985) demonstrated that vacation activity preferences are influenced by the perceived level of lifestyle stimulation inherent in the tourist's work, social life, and leisure time activities. Activities in a vacation destination can be decided before or after arrival in the destination (McKercher \& Chan, 2005). Furthermore, lifestyle information is widely used as a market segmentation tool. Schul and Crompton's (1983) study assessed the travel behaviour of international travellers using 16 travel-specific psychographic statements. Their study suggested that lifestyle research could provide a detailed profile of the respondents, segment respondents into different groups, and could predict respondents’ behaviour better than demographic variables.

Tourists may travel to escape from the ordinary and thus choose activities different to those at home, or may undertake the same activities as they do at home (Funk, Toohey, \& Bruun, 2007; Smith, Pitts, \& Litvin, 2012). In either case, lifestyle preferences or habitus are likely to influence their destination activity choices (Allen, 2002; Hjalager, 2004). This study will thus investigate the relationships between travel lifestyle preferences and participation in destination activities for a group with a particular lifestyle preference: Slow Food members.

The Slow Food movement is a non-profit foundation with over 20 years of history, and with over 100,000 members in 150 countries around the world. The philosophy of Slow Food is based on acquiring good, clean, and fair food: food should be tasty, varied, produced to maximise its flavour, and with connections to a geographic and cultural region; it should help to preserve rather than destroy the environment; and it should be produced in socially sustainable ways, with an emphasis on social justice and fair wages (Schneider, 2008). Food is an important component of Slow Food members' lifestyle, and members practice the Slow Food philosophy in their daily lives. It might thus be considered part of their habitus. Based on the view prevailing in definitions of food tourism, it may therefore be expected that Slow Food members' vacation travel would be motivated by their high interest in food. The Slow Food movement can also be associated with slow travel and tourism in the way that people behave and consume in their travel destination, as the movement is linked to ethical 
consumption, relocalisation of consumption, local food systems, food miles, and carbon footprint of food (Hall, 2012). Slow Food members tend to extend Slow Food core values into other consumption behaviours such as transportation, travel and vacation (Nevison, 2008).

The study thus aims to investigate the relationship between travel lifestyle preferences and participation in activities at a destination, and to compare Slow Food members and non-members in this regard. It was reasoned that the Slow Food members' lifestyle preferences in relation to Slow Food would influence their choice of activities in a travel destination to a greater extent than would be the case for non-members. It was therefore hypothesised that (1) Slow Food members would have different travel lifestyle preferences than non-members; (2) (a) Slow Food members would engage in different destination activities than non-members and (b) Slow Food members would be more consistent in their activity choices than non-members (i.e., less likely to vary in activities from one vacation to the next); and (3) travel lifestyle preferences would influence destination activity choices for both groups, but in different ways.

\section{Method}

\subsection{Procedure and Participants}

Two groups with an interest in food participated in the study: 337 members of the international Slow Food movement; and 207 visitors to a local food event in Brisbane, Australia.

An online survey was conducted with Slow Food members. The online survey initially targeted Slow Food members in English-speaking countries; however, due to the difficulty of collecting a large enough sample, the survey was extended to other countries. The survey was translated from English, using a back-translation technique into Italian, Spanish, Japanese, Korean and Chinese. The nationalities who responded to the online survey approximately represented the international Slow Food community, with the majority of respondents from Italy (60\%) and English-speaking countries (Australia, USA, UK, Canada, and South Africa, 35\%). An on-site survey with non-members was conducted using a face-to-face convenience intercept method with attendees at the Brisbane Good Food and Wine Show.

The gender distribution of Slow Food members was 45\% females and 55\% males; and for nonmembers was 60\% female and 40\% males. Most (75\%) Slow Food members were over 40 years old, while most (66\%) non-members were between 18 to 39 years old. These demographic differences between Slow Food members and non-members need to be taken into account in interpreting the data.

\subsection{Instruments}

The online and on-site questionnaires measured travel lifestyle preferences and destination activities.

\section{Travel lifestyle preferences}

A scale formulated by Schul and Crompton (1983) was used to measure travel-specific lifestyle. In Schul and Crompton's study, the original 16 travel activity, interest, and opinion statements reflected six underlying factors: (1) cultural interest; (2) comfort; (3) familiarity/convenience; (4) activity; (5) opinion leadership; and (6) knowledge-seeking. The 16 items were each rated on a seven-point Likerttype scale from "strongly disagree" to "strongly agree". 
Travel lifestyle data from the full data-set (including both Slow Food members and non-members) were analysed using Principal Axis factoring with Varimax rotation. On the initial factor analysis, the Kaiser-Meyer-Olkin (KMO) measure of sampling adequacy was .736 and the Barlett's Test of Sphericity $\chi_{(120)}^{2}=1657.251, p<.001$, indicating that the data were suitable for factor analysis. However, five items with communalities below .2 were eliminated. The criteria used to identify the number of factors was Kaiser's criterion of eigenvalues $>1$. Three factors (preference for familiarity and comfort, interest in new and local culture, preference for activity and adventure) were identified. Table 1 shows the results of the factor analysis of travel lifestyle items and Cronbach's alpha for each of the three factors.

Table 1. Principal Axis Factoring with Varimax rotation of Travel Lifestyle items

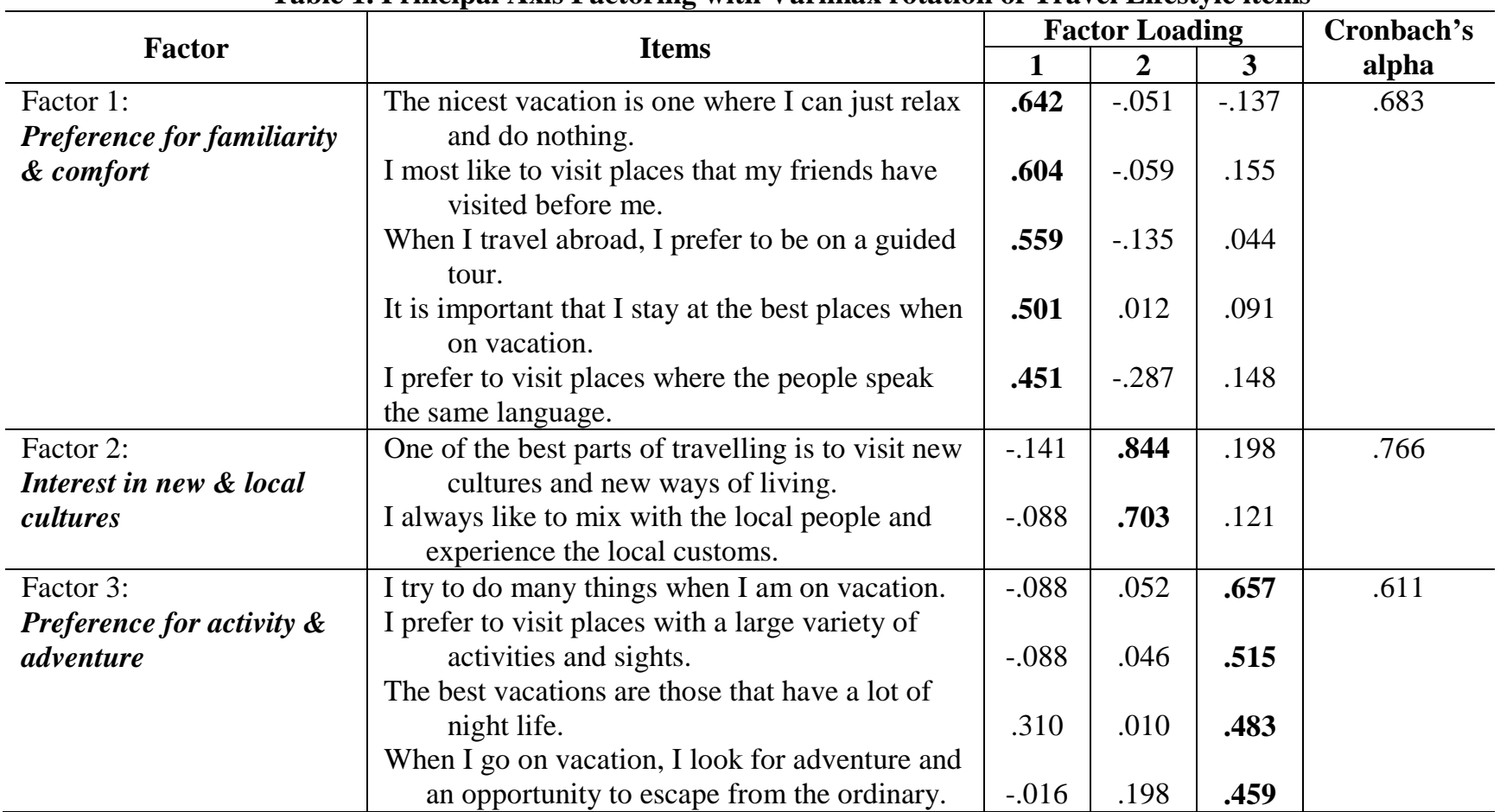

\section{Destination activities}

A new scale was created in order to measure food and travel-related activities in a destination. Selection of items was informed by findings from semi-structured face-to-face interviews with 43 international Slow Food members from Australia, Italy, Argentina, Taiwan and Hong Kong (Lee, 2013). Interviewees were asked about their general travel behaviour and their activity preferences in their vacation destinations. A total of 20 common activities were identified and submitted to two pilot tests, one with Slow Food members and one with non-members. The scales were further refined through factor analysis in order to select items that represented two distinct constructs: food-related activities and travel-related activities:

\section{Food-activity in the destination}

- I like to join cooking classes on my trips if possible.

- I like to cook my own meals on my trips if possible.

- I like to try local street food in a destination.

- I do not eat local food of a destination; I prefer food that I am familiar with.

- I like to read recipes/menus in the destination.

- I like to buy cook books in the destination.

- I like to buy local produce in the destination.

- I like to join food events/festivals. 


\section{Travel-activity in the destination}

- I prefer staying in small/family owned hostels rather than big chain hotels.

- I like to visit farmer/traditional markets in a destination.

- I like to stay in one destination as long as possible.

- I like to live like a local in the destination.

- I like to have flexibility in my itineraries.

- I like to enjoy a destination slowly.

- I like to visit Slow City (Cittàslow) destinations.

Respondents were asked to rate each item according to their preferences when on a vacation trip, using a six-point Likert-type scale from 1=Strongly Disagree to 6=Strongly Agree. An additional option "Varies" was provided, which respondents were asked to use if the importance of the item varied from one vacation to the next. This option was provided to investigate whether there was a difference between Slow Food members and non-members in the extent to which their preference for various destination activities was consistent from one vacation to another (Hypothesis $2 \mathrm{~b}$ ). When testing the other hypotheses based on destination activity preferences, two different methods were used to deal with the "Varies" responses. In Method 1, the "Varies" responses were treated as missing data, thus reducing the sample size. In Method 2, the "Varies" responses were recoded as the midpoint (4) of a 7-point scale from 1=Strongly Disagree to 7=Strongly Agree. Both methods were used for each analysis and any discrepancies in results are reported.

An initial factor analysis using Principal Axis Factoring with Varimax rotation was performed on the 8 food-activity items. The initial sample size was 522, but when using Method 1 ("Varies" responses as missing data), the sample size was reduced to 323. For Method 1, the Kaiser-Meyer-Olkin (KMO) measure of sampling adequacy of these items was .808 and the Barlett's Test of Sphericity $\chi^{2}$ ${ }_{(28)}=630.082, p<.001$. As the communalities of all items were above .2, no item was eliminated. Two factors underlying destination food activity preferences were identified (engagement in food activities and savouring local flavours) by using Kaiser's criterion of eigenvalues $>1$. Table 2 shows the results of the factor analysis of destination food activities and Cronbach's alpha for each factor. The same analysis was performed using Method 2 ("Varies" as the mid-point 4). A similar number of factors, factor loadings, and Cronbach’s alphas were obtained.

Table 2. Principal Axis Factoring of Destination Food-activities

\begin{tabular}{|c|c|c|c|c|}
\hline \multirow{2}{*}{ Factor } & \multirow{2}{*}{ Items } & \multicolumn{2}{|c|}{ Factor Loading } & \multirow{2}{*}{$\begin{array}{l}\text { Cronbach's } \\
\text { alpha }\end{array}$} \\
\hline & & 1 & 2 & \\
\hline \multirow{6}{*}{$\begin{array}{l}\text { Factor 1: Engagement in } \\
\text { food activities }\end{array}$} & I like to buy cook books in the destination. & .751 & .146 & \multirow[t]{6}{*}{.765} \\
\hline & $\begin{array}{l}\text { I like to join cooking classes on my trips if } \\
\text { possible. }\end{array}$ & .629 & .215 & \\
\hline & I like to buy local produce in the destination. & .578 & .404 & \\
\hline & I like to read recipes/menus in the destination. & .555 & .204 & \\
\hline & I like to cook my own meals on my trips if & .456 & .064 & \\
\hline & I like to join food events/festivals. & .416 & .338 & \\
\hline \multirow[t]{2}{*}{$\begin{array}{l}\text { Factor 2: Savouring local } \\
\text { flavours }\end{array}$} & $\begin{array}{l}\text { I do not eat local food of a destination; I prefer } \\
\text { food that I am familiar with. }\end{array}$ & .088 & .757 & \multirow[t]{2}{*}{.602} \\
\hline & I like to try local street food in a destination. & .243 & .568 & \\
\hline
\end{tabular}

The seven travel-activity items were similarly subjected to Principal Axis Factoring with Varimax rotation. The initial sample size was 512, but when using Method 1 ("Varies" responses as missing data), the sample size was reduced to 292. For Method 1, the Kaiser-Meyer-Olkin (KMO) measure of sampling adequacy of these items was .766 and the Barlett's Test of Sphericity $\chi_{(21)}^{2}=482.393$, $p<.001$. One item ("I like to stay in one destination as long as possible") was eliminated due to low communality $(<.2)$. One factor underlying destination travel-activity (immersion in the destination) 
was identified. Table 3 shows the results of factor analysis of destination travel-activities and Cronbach's alpha for the Immersion in destination factor. The same analysis was performed using Method 2 ("Varies" as the mid-point 4), yielding a similar number of factors, factor loadings, and Cronbach's alphas.

Table 3. Principal Axis Factoring of Destination Travel activities

\begin{tabular}{l|l|c|c}
\multicolumn{1}{c|}{ Factor } & \multicolumn{1}{c|}{ Items } & $\begin{array}{c}\text { Factor } \\
\text { Loading }\end{array}$ & $\begin{array}{c}\text { Cronbach's } \\
\text { alpha }\end{array}$ \\
\hline $\begin{array}{l}\text { Factor: Immersion in the } \\
\text { destination }\end{array}$ & $\begin{array}{l}\text { I like to visit Slow City (Cittàslow) destinations. } \\
\text { I like to visit farmer/traditional markets in a } \\
\text { destination. }\end{array}$ & $\mathbf{. 6 3 4}$ & .750 \\
& $\begin{array}{l}.629 \\
\text { I like to live like a local in the destination. }\end{array}$ & $\mathbf{. 6 0 9}$ \\
& I like to enjoy a destination slowly. & .597 \\
& I like to have flexibility in my itineraries. & .542 & \\
& I prefer staying in small/family owned hostels \\
& rather than big chain hotels. & .531 & \\
\hline
\end{tabular}

\section{Results}

\section{1 Hypothesis 1: Slow Food members have different travel lifestyle preferences than non-members}

An independent samples t-test was employed to investigate if statistically significant differences existed between Slow Food members and non-members in any of the three travel lifestyle factors. Table 4 indicates significant differences across all three factors. The results support the hypothesis that Slow Food members and non-members had different travel lifestyles; Slow Food members were more interested than non-members in new and local cultures, were less concerned about familiarity and comfort in their travel, and less interested in activity and adventure when on vacation. As nonmembers were younger than Slow Food members it was possible that this might influence their preference for activity and adventure in the destination. The effect of age was analysed using twoway ANOVA with two fixed factors: member (or not) of Slow Food and age (18 39 years, 40 59 years, $\geq 60$ years). The main effect of Slow Food membership was significant across all three travel lifestyle factors, even when age was accounted for $\left(F_{(1,503)}=7.157, p=.008\right.$, effect size $=.014$; $F_{(1,515)}=7.824, p=.005$, effect size $=.015 ; F_{(1,506)}=6.619, p=.010$, effect size=.013). The main effect of age was significant only in preference for activity and adventure. The interaction effect was not significant for any of the three travel lifestyle factors.

Table 4. Travel lifestyle differences between Slow Food members and non-members

\begin{tabular}{|c|c|c|c|c|c|}
\hline \multirow[t]{2}{*}{ Travel Lifestyle Factors } & \multicolumn{2}{|c|}{$\begin{array}{c}\text { Slow Food Members } \\
\text { (SF) }\end{array}$} & \multicolumn{2}{|c|}{$\begin{array}{c}\text { Non-Slow Food } \\
\text { participants (NSF) }\end{array}$} & \multirow[t]{2}{*}{ t-test results } \\
\hline & Mean & SD & Mean & SD & \\
\hline Preference for familiarity \& comfort & 3.40 & .98 & 3.78 & 1.10 & $\begin{array}{c}\mathrm{t}(520)=-4.10 \\
p<.001\end{array}$ \\
\hline Interest in new \& local cultures & 6.27 & .72 & 5.77 & .94 & $\begin{array}{c}\mathrm{t}(532)=6.88 \\
p<.001\end{array}$ \\
\hline Preference for activity \& adventure & 4.59 & .89 & 5.03 & .91 & $\begin{array}{c}\mathrm{t}(522)=-5.44 \\
p<.001\end{array}$ \\
\hline
\end{tabular}

Note. Items were rated on a 7-point scale from 1= 'strongly disagree’ to 7= 'strongly agree’.

3.2 Hypothesis 2: (a) Slow Food members engage in different destination activities than non-members 
An independent samples t-test was employed to investigate if statistically significant differences existed between Slow Food members and non-members in any of the three destination activity factors. Data was analysed first using Method 1 ("Varies" as missing), which reduced the sample size to 292. Table 5 indicates significant differences across all three destination activity factors with Slow Food members showing a higher interest than non-members in both food and travel-related activities. Slow Food members reported a greater preference for engaging in food activities, savouring local flavours, and immersing themselves in the destination than non-members. The same analysis was performed using Method 2 ("Varies" as mid-point), the sample size being 492. Table 6 shows the results using Method 2. The same pattern in the results was shown using both methods, although the means using method 2 are higher as they are based on a 7-point rather than 6-point scale. The findings confirmed a similar finding from past studies where Slow Food members showed an affinity for slow tourism and engaged in more interactions with local people (Hall, 2012; Nevison, 2008). The effect of age was investigated using two-way ANOVA. The significant-main effect of Slow Food membership remained significant across all three destination activity factors, there was no significant main effect for age and no interaction effect. Similar results were found using Method 1 and Method 2.

Table 5. Destination activity preference differences between Slow Food members and non-members (Method 1)

\begin{tabular}{c|l|c|c|c|c|c}
\hline \multicolumn{2}{c}{ Destination Activity Factors } & $\begin{array}{c}\text { Slow Food Members } \\
\text { (SF) }\end{array}$ & \multicolumn{2}{c}{$\begin{array}{c}\text { Non-Slow Food } \\
\text { participants (NSF) }\end{array}$} & \multirow{2}{*}{ t-test results } \\
\cline { 3 - 6 } & Mean & SD & Mean & SD & \\
\hline \multirow{2}{*}{ Food-activity } & Engagement in food activities & 4.86 & .67 & 4.06 & $\begin{array}{c}.90 \\
\mathrm{t}(344)=9.33, \\
p<.001\end{array}$ \\
\cline { 2 - 6 } & Savouring local flavours & 5.16 & .89 & 4.86 & 1.11 & $\begin{array}{c}\mathrm{t}(451)=3.14, \\
p=.002\end{array}$ \\
\hline Travel-activity & Immersion in the destination & 5.22 & .49 & 4.34 & .75 & $\begin{array}{c}\mathrm{t}(292)=11.65, \\
p<.001\end{array}$ \\
\hline
\end{tabular}

Note. Items were rated on a 6-point scale from 1= ‘strongly disagree' to 6 = 'strongly agree’.

Table 6. Destination activity preference differences between Slow Food members and non-members (Method 2)

\begin{tabular}{|c|c|c|c|c|c|c|}
\hline \multirow{2}{*}{\multicolumn{2}{|c|}{ Destination Activity Factors }} & \multicolumn{2}{|c|}{$\begin{array}{l}\text { Slow Food Members } \\
\text { (SF) }\end{array}$} & \multicolumn{2}{|c|}{$\begin{array}{c}\text { Non-Slow Food } \\
\text { participants (NSF) }\end{array}$} & \multirow{3}{*}{$\begin{array}{c}\text { t-test results } \\
\mathrm{t}(492)=9.41 \\
p<.001\end{array}$} \\
\hline & & Mean & SD & Mean & SD & \\
\hline \multirow{2}{*}{ Food-activity } & Engagement in food activities & 5.54 & .85 & 4.71 & 1.12 & \\
\hline & Savouring local flavours & 5.92 & 1.12 & 5.62 & 1.34 & $\begin{array}{c}\mathrm{t}(512)=2.65 \\
p=.008\end{array}$ \\
\hline Travel-activity & Immersion in the destination & 5.92 & .725 & 5.01 & .83 & $\begin{array}{c}\mathrm{t}(499)=12.74, \\
p<.001\end{array}$ \\
\hline
\end{tabular}

Note. Items were rated on a 7-point scale from 1= 'strongly disagree’ to 7 = 'strongly agree’, with 'varies' as the midpoint.

\subsection{Hypothesis 2: (b) Slow Food members are more consistent in their activity choices than non-members (i.e., less likely to vary in activities from one vacation to the next)}

The option "Varies" was added to the six-point rating scale as a seventh option to investigate whether there was a difference between Slow Food members and non-members in the extent to which their preference for various destination activities was consistent from one vacation to another. Table 7 presents the percentage of respondents who chose "Varies" in each of the destination activity items. Fewer than $12 \%$ of respondents chose the option "Varies" in most of the items (12 items out of 15) which suggests respondents were mostly consistent in their preferences and their answers were not perceived to vary from one vacation to another. Slow Food members "Varies" responses ranged from 
5-23\%, while non-members ranged from 4-30\%. On 12 of the 15 items, the differences between Slow Food members and non-members was not in the predicted direction, thus the hypothesis that Slow Food members are more consistent than non-members is not supported. The only item on which Slow Food members reported a significantly lower percentage of "Varies" responses than non-members was "I like to visit Slow City destinations". It is possible that non-members were not aware of the notion "Slow City" and chose "Varies” to express “Don’t know".

Table 7. Differences between Slow Food members and non-members in preference consistency

\begin{tabular}{|c|c|c|c|c|c|c|c|}
\hline & Items & $\begin{array}{c}\text { SF } \\
\text { Members } \\
\% \text { (n) } \\
\end{array}$ & $\begin{array}{c}\text { NSF } \\
\text { Members } \\
\% \text { (n) } \\
\end{array}$ & $\begin{array}{l}\text { Total } \% \\
\text { (n) }\end{array}$ & $\begin{array}{c}X^{2} \\
\text { value }\end{array}$ & \multirow[t]{2}{*}{$d f$} & \multirow[t]{2}{*}{$p$} \\
\hline & $\begin{array}{l}\text { I like to join cooking classes on } \\
\text { my trips if possible. }\end{array}$ & 10.9\%(37) & $7.2 \%(15)$ & $9.6 \%(52)$ & & & \\
\hline & $\begin{array}{l}\text { I like to cook my own meals on } \\
\text { my trips if possible. }\end{array}$ & $13.3 \%(45)$ & $7.2 \%(15)$ & $11 \%(60)$ & & & \\
\hline \multirow{6}{*}{$\begin{array}{l}\text { Food- } \\
\text { activity }\end{array}$} & $\begin{array}{l}\text { I like to try local street food in a } \\
\text { destination. }\end{array}$ & $10.8 \%(34)$ & $4.3 \%(9)$ & 7.9\%(43) & & & \\
\hline & $\begin{array}{l}\text { I do not eat local food of a } \\
\text { destination; I prefer food that I } \\
\text { am familiar with. }\end{array}$ & $5.3 \%(18)$ & $6.7 \%(14)$ & $5.9 \%(32)$ & .507 & 1 & .600 \\
\hline & $\begin{array}{l}\text { I like to read recipes/menus in } \\
\text { the destination. }\end{array}$ & $6.5 \%(22)$ & $5.3 \%(11)$ & $6 \%(33)$ & & & \\
\hline & $\begin{array}{l}\text { I like to buy cook books in the } \\
\text { destination. }\end{array}$ & $9.1 \%(31)$ & $6.2 \%(13)$ & $8 \%(44)$ & & & \\
\hline & $\begin{array}{l}\text { I like to join food } \\
\text { events/festivals. }\end{array}$ & $8.9 \%(30)$ & $4.3 \%(9)$ & 7.2\%(39) & & & \\
\hline & $\begin{array}{l}\text { I like to buy local produce in the } \\
\text { destination. }\end{array}$ & $9.4 \%(32)$ & $5.7 \%(12)$ & $8 \%(44)$ & & & \\
\hline \multirow{7}{*}{$\begin{array}{l}\text { Travel- } \\
\text { activity }\end{array}$} & $\begin{array}{l}\text { I prefer staying in small/family } \\
\text { owned hostels rather than big } \\
\text { chain hotels. }\end{array}$ & $16.6 \%(56)$ & $22.7 \%(47)$ & $19 \%(103)$ & 3.575 & 1 & .076 \\
\hline & $\begin{array}{l}\text { I like to stay in one destination as } \\
\text { long as possible. }\end{array}$ & $22.8 \%(77)$ & $12.6 \%(26)$ & $19 \%$ (103) & & & \\
\hline & $\begin{array}{l}\text { I like to visit farmer/traditional } \\
\text { markets in a destination. }\end{array}$ & $6.5 \%(22)$ & $5.7 \%(12)$ & $6.3 \%(34)$ & & & \\
\hline & $\begin{array}{l}\text { I like to live like a local in the } \\
\text { destination. }\end{array}$ & $10.7 \%(36)$ & $7.7 \%(16)$ & $9.6 \%(52)$ & & & \\
\hline & $\begin{array}{l}\text { I like to have flexibility in my } \\
\text { itineraries. }\end{array}$ & $8.9 \%(30)$ & $2.8 \%(6)$ & $6.6 \%(36)$ & & & \\
\hline & $\begin{array}{l}\text { I like to enjoy a destination } \\
\text { slowly. }\end{array}$ & $8.3 \%(28)$ & $10.6 \%(22)$ & $9.2 \%(50)$ & 1.201 & 1 & .346 \\
\hline & $\begin{array}{l}\text { I like to visit Slow City } \\
\text { (Cittàslow) destinations. }\end{array}$ & $8.9 \%(30)$ & $29.9 \%(62)$ & $16.9 \%(92)$ & 47.016 & 1 & .000 \\
\hline
\end{tabular}

Note. Chi-square results are reported only for items where the differences between groups were in the predicted direction (SF < NSF) with the exception of the last item[JP1].

3.4 Hypothesis 3: travel lifestyle preferences influence destination activity choices for both groups, but in different ways 
The three travel lifestyle factors were as entered into a regression analysis as independent variables, with Each of the three destination activity factors was entered into a stepwise regression analysis as a dependent variable usingeach of the three destination activity factors, in turn, as the dependent variable-the three travel lifestyle factors as independent variables. The analysis was performed first for all cases, and then each group (Slow Food members and non-members) was analysed separately.

\subsubsection{The relationship between travel lifestyle factors and-destination-activity-Engagement in food activities}

Table 8 shows the results of the standard-regression analysis using the Enter method for predicting engagement in food activities. Only interest in new and local cultures was found to have significant relationship with engagement in food activities using both Method 1 and Method 2. It seems that participants' preference to undertake food activities in the destination is associated with their interest in new and local cultures of the destination.

The results from separate regression analyses per group (Slow Food members and non-members) showed similar results, with interest in new and local cultures having the strongest effect on engagement in food activities for both groups. Preference for activity and adventure also had a small but significant positive influence on engagement in food activities for Slow Food members. A Fisher's z-test was used to determine whether there was a significant difference in the $\mathrm{R}$ values between the Slow Food members and non-members-group. No significant difference was found.

Table 8. Standard (enter) multiple regression analysis for predicting engagement in food activities

\begin{tabular}{|c|c|c|c|c|c|c|c|c|}
\hline All participants & $\begin{array}{c}\text { Sample } \\
\text { Size }\end{array}$ & $\begin{array}{c}\text { Beta } \\
\text { (ß) }\end{array}$ & Sig. & $\mathbf{R}$ & $\mathbf{R}^{2}$ & Adj. $R^{2}$ & $\boldsymbol{F}$ & Fisher z-test \\
\hline $\begin{array}{l}\text { Method } 1 \\
\text { Preference for familiarity \& comfort } \\
\text { Interest in new \& local cultures } \\
\text { Preference for activity \& adventure }\end{array}$ & 346 & $\begin{array}{l}-.081 \\
.399 \\
-.040\end{array}$ & $\begin{array}{l}.127 \\
.000 \\
.440\end{array}$ & .423 & .179 & .171 & $24.010 * * *$ & \\
\hline $\begin{array}{l}\text { Method } 2 \\
\text { Preference for familiarity \& comfort } \\
\text { Interest in new \& local cultures } \\
\text { Preference for activity \& adventure }\end{array}$ & 494 & $\begin{array}{l}-.050 \\
.350 \\
-.073\end{array}$ & $\begin{array}{l}.920 \\
.000 \\
.107\end{array}$ & .344 & .118 & .113 & $21.163^{* * *}$ & \\
\hline \multicolumn{9}{|l|}{ Sub-group (Method 1) } \\
\hline $\begin{array}{l}\text { Slow Food members } \\
\text { Preference for familiarity \& comfort } \\
\text { Interest in new \& local cultures } \\
\text { Preference for activity \& adventure }\end{array}$ & 206 & $\begin{array}{l}-.063 \\
.295 \\
.175\end{array}$ & $\begin{array}{l}.349 \\
.000 \\
.012\end{array}$ & .395 & .156 & .143 & $11.978^{* * *}$ & \multirow[t]{2}{*}{$\begin{array}{c}\text { z-score }= \\
.637 \\
p=.524\end{array}$} \\
\hline $\begin{array}{l}\text { Non-members } \\
\text { Preference for familiarity \& comfort } \\
\text { Interest in new \& local cultures } \\
\text { Preference for activity \& adventure }\end{array}$ & 140 & $\begin{array}{l}-.028 \\
.334 \\
-.055\end{array}$ & $\begin{array}{l}.750 \\
.000 \\
.540\end{array}$ & .334 & .111 & .091 & $5.563 * * *$ & \\
\hline \multicolumn{9}{|l|}{ Sub-group (Method 2) } \\
\hline $\begin{array}{l}\text { Slow Food members } \\
\text { Preference for familiarity \& comfort } \\
\text { Interest in new \& local cultures } \\
\text { Preference for activity \& adventure }\end{array}$ & 312 & $\begin{array}{l}.035 \\
.209 \\
.113 \\
\end{array}$ & $\begin{array}{l}.545 \\
.000 \\
.057\end{array}$ & .263 & .069 & .060 & $7.335 * * *$ & \multirow[t]{2}{*}{$\begin{array}{c}\text { Z-score }= \\
-.518 \\
p=.561\end{array}$} \\
\hline $\begin{array}{l}\text { Non-members } \\
\text { Preference for familiarity \& comfort } \\
\text { Interest in new \& local cultures } \\
\text { Preference for activity \& adventure }\end{array}$ & 182 & $\begin{array}{c}.013 \\
.333 \\
-.100 \\
\end{array}$ & $\begin{array}{l}.872 \\
.000 \\
.204 \\
\end{array}$ & .313 & .098 & .082 & $6.296 * * *$ & \\
\hline
\end{tabular}

Note. ${ }^{* * *} p<.001$ 


\subsubsection{The relationship between travel lifestyle factors and destination activity-Savouring local flavours}

Table 9 shows the results of the standard-regression analysis using the Enter method for predicting savouring local flavours for all participants and sub-groups. Similar results were found using Method 1 and Method 2, and for both Slow Food members and non-members. Preference for familiarity and comfort showed a moderate-negative relationship with savouring local flavours, while interest in new and local culture had a moderate-positive relationship. It seemed that participants who had a low preference for familiarity and comfort in their travel and a high interest in new and local culture were more likely to savour local flavours in the destination. A Fisher's z-test was used to determine whether there was a significant difference in the $\mathrm{R}$ values between the Slow Food members and non-members group. No significant difference was found.

Table 9. Standard (enter) multiple regression analysis for predicting savouring local flavours

\begin{tabular}{|c|c|c|c|c|c|c|c|c|}
\hline All participants & $\begin{array}{c}\text { Sample } \\
\text { Size } \\
\end{array}$ & $\begin{array}{c}\text { Beta } \\
\text { (ß) }\end{array}$ & Sig. & $\mathbf{R}$ & $\mathbf{R}^{2}$ & Adj. $R^{2}$ & $\boldsymbol{F}$ & Fisher z-test \\
\hline $\begin{array}{l}\text { Method } 1 \\
\text { Preference for familiarity \& comfort } \\
\text { Interest in new \& local cultures } \\
\text { Preference for activity \& adventure }\end{array}$ & 453 & $\begin{array}{l}-.384 \\
.327 \\
-.002\end{array}$ & $\begin{array}{l}.000 \\
.000 \\
.954\end{array}$ & .557 & .311 & .306 & $65.202 * * *$ & \\
\hline $\begin{array}{l}\text { Method } 2 \\
\text { Preference for familiarity \& comfort } \\
\text { Interest in new \& local cultures } \\
\text { Preference for activity \& adventure }\end{array}$ & 514 & $\begin{array}{l}-.377 \\
.265 \\
.009\end{array}$ & $\begin{array}{l}.000 \\
.000 \\
.830\end{array}$ & .510 & .260 & .256 & $57.677 * * *$ & \\
\hline \multicolumn{9}{|l|}{ Sub-group (Method 1) } \\
\hline $\begin{array}{l}\text { Slow Food members } \\
\text { Preference for familiarity \& comfort } \\
\text { Interest in new \& local cultures } \\
\text { Preference for activity \& adventure }\end{array}$ & 276 & $\begin{array}{l}-.406 \\
.279 \\
-.039\end{array}$ & $\begin{array}{l}.000 \\
.000 \\
.486\end{array}$ & .520 & .271 & .262 & $32.195 * * *$ & \multirow[t]{2}{*}{$\begin{array}{c}\text { z-score }= \\
-.734 \\
p=.463\end{array}$} \\
\hline $\begin{array}{l}\text { Non-members } \\
\text { Preference for familiarity \& comfort } \\
\text { Interest in new \& local cultures } \\
\text { Preference for activity \& adventure }\end{array}$ & 177 & $\begin{array}{l}-.362 \\
.350 \\
.044\end{array}$ & $\begin{array}{l}.000 \\
.000 \\
.524\end{array}$ & .570 & .325 & .313 & $27.318 * * *$ & \\
\hline \multicolumn{9}{|l|}{ Sub-group (Method 2) } \\
\hline $\begin{array}{l}\text { Slow Food members } \\
\text { Preference for familiarity \& comfort } \\
\text { Interest in new \& local cultures } \\
\text { Preference for activity \& adventure }\end{array}$ & 320 & $\begin{array}{l}-.389 \\
.193 \\
-.029\end{array}$ & $\begin{array}{l}.000 \\
.000 \\
.585\end{array}$ & .459 & .211 & .203 & $26.905 * * *$ & \multirow[t]{2}{*}{$\begin{array}{c}\text { z-score }= \\
-1.446 \\
p=.148\end{array}$} \\
\hline $\begin{array}{l}\text { Non-members } \\
\text { Preference for familiarity \& comfort } \\
\text { Interest in new \& local cultures } \\
\text { Preference for activity \& adventure }\end{array}$ & 194 & $\begin{array}{l}-.356 \\
.336 \\
.042\end{array}$ & $\begin{array}{l}.000 \\
.000 \\
.533\end{array}$ & .557 & .311 & .300 & $27.940 * * *$ & \\
\hline
\end{tabular}

\subsubsection{The relationship between travel lifestyle factors and destination activity-Immersion in the destination}

Table 10 shows the results of the standard-regression analysis using the Enter method for predicting immersion in the destination for all participants and sub-groups. Similar results were found using Method 1 and Method 2, and for Slow Food members and non-members. Only interest in new and local culture revealed a positive strong significant influence ond to immersion in the destination. The results suggest that participants-_who express an interest in local food and culture influences their preferenceare more likely to immerse themselves in the destination. 
When analysing per group (Slow Food members and non-members), preference for familiarity and comfort also showed a significant and-negative influence on immersion in the destination for nonmembers only. Thus non-members were more likely to immerse themselves in a destination when they were less concerned about familiarity and comfort in their travel. There were no significant difference between the $\mathrm{R}$ values for Slow Food members and non-members.

Table 10. Standard (enter) multiple regression analysis for predicting immersion in the destination

\begin{tabular}{|c|c|c|c|c|c|c|c|c|}
\hline All participants & $\begin{array}{c}\text { Sample } \\
\text { Size }\end{array}$ & $\begin{array}{c}\text { Beta } \\
\text { (ß) }\end{array}$ & Sig. & $\mathbf{R}$ & $\mathbf{R}^{2}$ & Adj. $R^{2}$ & $\boldsymbol{F}$ & Fisher z-test \\
\hline $\begin{array}{l}\text { Method } 1 \\
\text { Preference for familiarity \& comfort } \\
\text { Interest in new \& local cultures } \\
\text { Preference for activity \& adventure }\end{array}$ & 292 & $\begin{array}{l}-.118 \\
.500 \\
-.136 \\
\end{array}$ & $\begin{array}{l}.031 \\
.000 \\
.011 \\
\end{array}$ & .544 & .296 & .289 & $38.717 * * *$ & \\
\hline $\begin{array}{l}\text { Method } 2 \\
\text { Preference for familiarity \& comfort } \\
\text { Interest in new \& local cultures } \\
\text { Preference for activity \& adventure }\end{array}$ & 501 & $\begin{array}{l}-.055 \\
.426 \\
-.148\end{array}$ & $\begin{array}{l}.204 \\
.000 \\
.001 \\
\end{array}$ & .439 & .193 & .188 & $38.055^{* * *}$ & \\
\hline \multicolumn{9}{|l|}{ Sub-group (Method 1) } \\
\hline $\begin{array}{l}\text { Slow Food members } \\
\text { Preference for familiarity \& comfort } \\
\text { Interest in new \& local cultures } \\
\text { Preference for activity \& adventure }\end{array}$ & 206 & $\begin{array}{l}-.038 \\
.403 \\
.099\end{array}$ & $\begin{array}{l}.572 \\
.000 \\
.146 \\
\end{array}$ & .445 & .198 & .186 & $15.732 * * *$ & \multirow[t]{2}{*}{$\begin{array}{l}\text { Z-score }= \\
-.730 \\
p=.465\end{array}$} \\
\hline $\begin{array}{l}\text { Non-members } \\
\text { Preference for familiarity \& comfort } \\
\text { Interest in new \& local cultures } \\
\text { Preference for activity \& adventure }\end{array}$ & 86 & $\begin{array}{l}-.243 \\
.388 \\
-.178 \\
\end{array}$ & $\begin{array}{l}.026 \\
.001 \\
.108 \\
\end{array}$ & .518 & .268 & .241 & $9.896 * * *$ & \\
\hline \multicolumn{9}{|l|}{ Sub-group (Method 2) } \\
\hline $\begin{array}{l}\text { Slow Food members } \\
\text { Preference for familiarity \& comfort } \\
\text { Interest in new \& local cultures } \\
\text { Preference for activity \& adventure }\end{array}$ & 321 & $\begin{array}{l}.043 \\
.319 \\
.026 \\
\end{array}$ & $\begin{array}{l}.439 \\
.000 \\
.645 \\
\end{array}$ & .324 & .105 & .096 & $11.790 * * *$ & \multirow[t]{2}{*}{$\begin{array}{c}\text { z-score }= \\
-.959 \\
p=.337\end{array}$} \\
\hline $\begin{array}{l}\text { Non-members } \\
\text { Preference for familiarity \& comfort } \\
\text { Interest in new \& local cultures } \\
\text { Preference for activity \& adventure }\end{array}$ & 180 & $\begin{array}{c}-.168 \\
.335 \\
-.120 \\
\end{array}$ & $\begin{array}{l}.026 \\
.000 \\
.121 \\
\end{array}$ & .402 & .162 & .147 & $11.078^{* * *}$ & \\
\hline
\end{tabular}

Note. ${ }^{* * *} p<.001$

\section{Discussion}

Slow Food members and non-members presented different travel lifestyle preferences as well as destination activity choices. Slow Food members were more interested in local and new cultures while non-members had a higher preference for familiarity and comfort in their travel as well as preference for activity and adventure. (although aA ge differences may have been an influence in this regard, but the effect remained significant when age was accounted for). Past studies have shown that individuals' motivations and decisions to travel are based on internal and external factors such as cultural, social, psychological and lifestyle factors (Correia \& Pimpão, 2008; Decrop, 2006; Woodside, Caldwell, \& Spurr, 2006). Slow Food members in this study presented less interest in familiarity and comfort and higher interest in local culture than non-members. Slow Food members were also more likely than non-members to immerse themselves in a destination by interacting with the local community and enjoying the destination slowly.

However, the hypothesis that Slow Food members were more consistent than non-members in their destination activity choices was not supported, except for one item about visiting Slow City 
destinations. The extent to which these results might have been influenced by the age, profession or gender differences between these two groups requires further investigation.

This study also demonstrated that travel lifestyle preferences influence destination activity choices for both Slow Food members and non-members. Interest in new and local cultures was found to have a strong positive influence on all three destination activity factors. The higher the interest in local culture, the higher the preference in engaging in food activities, savouring local flavours, and immersion in the destination. Past studies have found that tourists' preference for familiar and comfortable travel decreases their interest in tasting local food as they would seek more familiar flavours in the destination (Chang, Kivela, \& Mak, 2010; Germann Molz, 2007). Bardhi, Ostberg, and Bengtsson's (2010) study documented the negative food experience encountered by American consumers in China due to their lack of knowledge about the local culture of the destination. In the present study, savouring local flavours in the destination was influenced negatively by the preference for familiarity and comfort in travel, and positively by the interest in new and local cultures.

Travel lifestyle influenced destination activity choices for both Slow Food members and nonmembers. The important influences were mostly similar between the two groups, however preference for activity and adventure had a positive influence on engagement in food activities for Slow Food members only, and preference for familiarity and comfort had a negative influence on immersion in the destination for non-members only. It seemed that members would be more likely to engage in food activities if they had a preference for activity and adventure, while non-members would be more likely to stay longer and interact with local people in a destination if they were not concerned about familiarity and comfort in their travel. Pizam and Jeong (1996) found tourists from different nationalities (Japanese, Koreans and Americans) had different travel behaviour (as perceived by tour guides), especially in the characteristic of "novelty vs. familiarity”. Basala and Klenosky (2001) also found that "familiarity seekers" preferred to stay in well-known international hotels or places with a high level of comfort and convenience while they travelled. The results of the present study support the observation that a preference for familiarity and comfort is an important lifestyle factor that impacts on engagement in destination activities, especially in relation to savouring local flavours. However, in the present study, interest in new and local cultures was also an important lifestyle factor, especially in relation to engaging in food activities and immersion in the local destination.

\section{Conclusion and implications}

While both groups of participants in this study had food interests, Slow Food members showed a stronger interest in new and local cultures as well as being more likely to undertake food-activities, savour local flavours and immerse themselves in the destination.

Past literature in food tourism proposes that participation in local food activities is driven by participants' interest in food. The present study suggests that this may not be a sufficient explanation. Even when-though tourists' initial motivation to travel to a destination might not be related to food, their participation in food activities in the destination is influenced by their travel lifestyle. In this case, the lifestyle of Slow Food members was reflected in their high interest in local culture and low concern for familiarity and comfort in their travel. The findings of this study suggest that tourists who are willing to accept and interact with new cultures tend to be more willing to try unfamiliar local food and experience local life. Their travel lifestyle influences their motivation to participate in foodrelated activities in the destination. Although the two groups of participants (Slow Food members and non-members) both had an interest in food, their motivation to participate in food-related activities was explained by their different travel lifestyle preferences. Lifestyle forms the habitus that a person 
carries wherever he or she goes and is manifested through consumption and choices of activities in the destination (Bourdieu, 1984; Hjalager, 2004).

The results of this study would assist destination managers and tourist operators to differentiate the kind of activities and events likely to attract tourists who are more engaged in food. For example, if a local food event in a destination would like to attract international tourists, it might be more likely that freelance tourists (tourists who have more time to interact with local people) would have a higher interest in attending this event than group tourists with a tour guide (tourists who like comfortable and familiar travel). Similarly, tourists who are interested in local culture would be more willing to taste traditional local food and get involved with local people. The findings of this study could also assist destination marketers to better understand the travel lifestyle of participants-tourists with an interest in food $_{2}$ and design an appropriate marketing mix to provide adequate services.

The diverse cultural background of Slow Food members may have impacted on the results of this study. It is a recommendation for future study to explore the influence of cultural factors on travel lifestyles, destination activities, and the relationships between them-perform a single culture comparison between Slow Food members and non-Slow Food participants within a single cultural group. There are other aspects of lifestyle that were not able to be coveredincluded in this paperstudy, and could be explored in. F future research-could explore the relationship of other lifestyle factors with destination activity preferences of tourists with an interest in food. The findings of this study suggest that the impact of travel lifestyle on engagement in destination activities is likely to be a fruitful area for future research.

\section{REFERENCES}

Ab Karim, S., \& Chi, C. G.-Q. (2010). Culinary Tourism as a Destination Attraction: An Empirical Examination of Destinations' Food Image. Journal of Hospitality Marketing \& Management, 19(6), 531-555.

Allen, D. E. (2002). Toward a Theory of Consumer Choice as Sociohistorically Shaped Practical Experience: The Fits-Like-a-Glove (FLAG) Framework. Journal of Consumer Research, 28(4), 515-532.

Au, N., \& Law, R. (2002). Categorical classification of tourism dining. Annals of Tourism Research, 29(3), 819-833.

Bardhi, F., Ostberg, J., \& Bengtsson, A. (2010). Negotiating cultural boundaries: Food, travel and consumer identities. Consumption Markets \& Culture, 13(2), 133-157.

Basala, S. L., \& Klenosky, D. B. (2001). Travel-Style Preferences for Visiting a Novel Destination: A Conjoint Investigation across the Novelty-Familiarity Continuum. Journal of Travel Research, 40(2), 172-182.

Bessiere, J. (1998). Local Development and Heritage: Traditional Food and Cuisine as Tourist Attractions in Rural Areas. Sociologia Ruralis, 38(1), 21-34.

Boniface, P. (2003). Tasting tourism: travelling for food and drink. Aldershot: Ashgate.

Bourdieu, P. (1984). Distinction: a social critique of the judgement of taste. Cambridge, Mass: Harvard University Press.

Bourdieu, P. (1990). The logic of practice. Cambridge: Polity Press.

Chang, R. C. Y., Kivela, J., \& Mak, A. H. N. (2010). Food preferences of Chinese tourists. Annals of Tourism Research, 37(4), 989-1011.

Chen, J. S., Huang, Y.-C., \& Cheng, J.-S. (2009). Vacation Lifestyle and Travel Behaviors. Journal of Travel \& Tourism Marketing, 26(5/6), 494-506.

Correia, A., \& Pimpão, A. (2008). Decision-making processes of Portuguese tourist travelling to South America and Africa. International Journal of Culture, Tourism and Hospitality Research, 2(4), 330-373.

Decrop, A. (2006). Vacation Decision-Making. Wallingford: CAB International. 
du Rand, G., Heath, E., \& Alberts, N. (2003). The Role of Local and Regional Food in Destination Marketing -- A South African Situation Analysis. Journal of Travel \& Tourism Marketing, 14(3), 97-112.

Frochot, I. (2003). An Analysis of Regional Positioning and Its Associated Food Images in French Tourism Regional Brochures. Journal of Travel \& Tourism Marketing, 14(3), 77-96.

Funk, D. C., Toohey, K., \& Bruun, T. (2007). International Sport Event Participation: Prior Sport Involvement; Destination Image; and Travel Motives. European Sport Management Quarterly, 7(3), 227 - 248.

Germann Molz, J. (2007). Eating Difference. The Cosmopolitan Mobilities of Culinary Tourism, 10(1), 77-93.

Hall, C. M. (2012). The Contradictions and Paradoxes of Slow Food: Environmental Change, Sustainability and the Conservation of Taste. In S. Fullagar, K. Markwell \& E. Wilson (Eds.), Slow Tourism: Experiences and Mobilities (pp. 53-68): Channel View Publications.

Hall, C. M., \& Mitchell, R. (2001). Wine and food tourism. In N. D. R. Derrett (Ed.), Special interest tourism (pp. 307-325). Australia: John Wiley.

Hall, C. M., \& Sharples, L. (2008). Food events, festivals and farmers' markets: An introduction. In C. M. Hall \& L. Sharples (Eds.), Food and wine festivals and events around the world: development, management and markets. Amsterdam: Elsevier/Butterworth-Heinemann.

Hjalager, A.-M. (2004). What do tourists eat and why? Towards a sociology of gastronomy and tourism. Tourism, 52(2), 195-201.

Hsu, T.-K., Tsai, Y.-F., \& Wu, H.-H. (2009). The preference analysis for tourist choice of destination: A case study of Taiwan. Tourism Management, 30(2), 288-297.

Kao, M. C., Patterson, I., Scott, N., \& Li, C. K. (2008). Motivations and Satisfactions of Taiwanese Tourists Who Visit Australia. Journal of Travel \& Tourism Marketing, 24(1), 17-33.

Kim, Y. H., Kim, M., Goh, B. K., \& Antun, J. M. (2011). The Role of Money: The Impact on Food Tourists' Satisfaction and Intention to Revisit Food Events. Journal of Culinary Science \& Technology, 9(2), 85-98.

Kivela, J., \& Crotts, J. C. (2005). Gastronomy Tourism: A Meaningful Travel Market Segment. Journal of Culinary Science \& Technology, 4(2/3), 39-55.

Kivela, J., \& Crotts, J. C. (2006). Tourism and Gastronomy: Gastronomy's Influence on How Tourists Experience a Destination. Journal of Hospitality \& Tourism Research, 30(3), 354377.

Lanzendorf, M. (2002). Mobility Styles and Travel Behavior: Application of a Lifestyle Approach to Leisure Travel. Transportation Research Record, 1807(1), 163-173.

Lee, K. H. (2013). Understanding the importance of food in vacation decision making-Involvement, lifestyles and destination activity preferences of international Slow Food members.

(Dissertation/Thesis), The University of Queensland, Australia.

Mak, A. H. N., Lumbers, M., \& Eves, A. (2012). Globalisation and food consumption in tourism. Annals of Tourism Research, 39(1), 171-196.

McKercher, B., \& Chan, A. (2005). How Special Is Special Interest Tourism? Journal of Travel Research, 44(1), 21-31.

McKercher, B., Okumus, F., \& Okumus, B. (2008). Food Tourism as a Variable Market Segment: It's all how you cook the numbers! Journal of Travel \& Tourism Marketing, 25(2), 137-148.

Moutinho, L. (1987). Consumer Behaviour in Tourism. European Journal of Marketing, 21(10), 544.

Nevison, J. (2008). Impact of sustainable consumption choices on quality of life. Unpublished MA (International Leadership) project, Simon Fraser University.

Pizam, A., \& Jeong, G.-H. (1996). Cross-cultural tourist behavior : Perceptions of Korean tourguides. Tourism Management, 17(4), 277-286.

Quan, S., \& Wang, N. (2004). Towards a structural model of the tourist experience: an illustration from food experiences in tourism. Tourism Management, 25(3), 297-305. 
Schneider, S. (2008). Good, Clean, Fair: The Rhetoric of the Slow Food Movement. College English, 70(4), 384-402.

Schul, P., \& Crompton, J. L. (1983). Search Behavior of International Vacationers: Travel-Specific Lifiestyle and Sociodemographic Variables. Journal of Travel Research, 22(2), 25-30.

Sirakaya, E., \& Woodside, A. G. (2005). Building and testing theories of decision making by travellers. Tourism Management, 26(6), 815-832.

Smallman, C., \& Moore, K. (2010). Process Studies of Tourists' Decision-Making. Annals of Tourism Research, 37(2), 397-422.

Smith, W. W., Pitts, R. E., \& Litvin, S. W. (2012). Travel and leisure activity participation. Annals of Tourism Research, 39(4), 2207-2210.

Sobel, M. E. (1981). Lifestyle and social structure: concepts, definitions, analyses. New York: Academic Press.

Veal, A. J. (1991). Lifestyle and leisure: a review and bibliography (Vol. no. 13.). Sydney: Centre for Leisure \& Tourism Studies, University of Technology.

Woodside, A. G., Caldwell, M., \& Spurr, R. (2006). Advancing Ecological Systems Theory in Lifestyle, Leisure, and Travel Research. Journal of Travel Research, 44(3), 259-272. 